\title{
Business internships and new technologies: a scenario for growth and innovation
}

\author{
Sanahuja Vélez, Gisela $^{\mathrm{a}}$; Ribes Giner, Gabriela ${ }^{\mathrm{a}}$ and Moya Clemente, Ismael ${ }^{\mathrm{a}}$ \\ ${ }^{a}$ Universitat Politècnica de València
}

\begin{abstract}
Literature on traineeships recognizes beneficial effects on its main agents: students, employers, and higher education institutions. Furthermore, some authors have identified added effects when applying new technologies to the business internship experience, specially referred to improved computer skills and learning outcomes. The Faculty of Business Administration and Management of the Universitat Politècnica de València has had a remarkable increase of internships in recent years. As computer skills are being more demanded by employers in a globalized and technological world, it is expected that virtual placements and ICTs in the internship practice will be a trend in universities in the up-coming years. The management of internships of the two new Double Degrees in the Faculty of Business: Business Administration and Management + Computer Science Engineering, and Business Administration and Management + Telecommunications Engineering, could provide the perfect scenario to put into practice and to explore the possibilities of new technologies applied to internships. The recent change in the Spanish law and in the regulations of universities, such as the Universitat Politècnica de València, allows business internships to take place abroad. This could also provide an opportunity for innovation and growth, by combining internationalization with virtualization of internships.
\end{abstract}

Keywords: Internship, Traineeship, Telecommuting, ICTs, Employability, Computer Skills. 


\section{Introduction}

On the one hand, past research on business traineeships has identified beneficial effects on its three main agents: students, employers, and higher education institutions (Coco, 2000; Divine, Linrud, Miller, \& Wilson, 2007; Gault, Redington, \& Schlager, 2000; Thiel \& Hartley, 1997). A systematic review of the scientific literature about business internships and their impact on their stakeholders by Sanahuja Vélez \& Ribes Giner (2015) listed high number of positive effects and stated that they are a win-win situation. Evidence proves the efficiency of business internships done by university students in enhancing their employability (Callanan \& Benzing, 2004; Cook, Parker, \& Pettijohn, 2004; Divine, et al., 2007; Gault, Leach, \& Duey, 2010; Gault, et al., 2000; Knouse \& Fontenot, 2008; Knouse, Tanner, \& Harris, 1999; Mihail, 2006; Taylor, 1988; Weible \& McClure, 2011). Also, the improvement of skills is remarked as another important beneficial effect on students (Beard \& Morton, 1999; Chen, 2011; Cook, et al. 2004; Divine et al., 2007; Gault, et al. 2000; Green, Graybeal, \& Madison, 2011; Gryski, Johnson, \& O’Toole, 1987; Knouse \& Fontenot, 2008; Knouse, et al., 1999; Mihail, 2006; Scholz, 2003; Taylor, 1988; Theil \& Hartley, 1997).

On the other hand, advances in technology, comprising high speed internet connections and low-cost portable devices, have made the virtual workplace a reality which is expected to grow (Franks \& Oliver, 2012). The labor market presents an increasing tendency to telecommuting, remote work or telework. "Telecommuting" is a work agreement in which employees do not travel to a central place of work. "Telework" refers to all types of technology-aided work conducted outside of a centrally sited work space (including work undertaken at home, outside calls, etc.). In the same way, institutions of higher education are beginning to recognize the value of virtual internship as valid experiential learning opportunities to acquire professional skills and competencies (Franks \& Oliver, 2012).

The aim of this research was to examine the literature published during the past ten years on the relation of business internships and new technologies. Our objective was also to analyze the current situation at the Universitat Politècnica de València in order to determine if the existing conditions would allow an opportunity for innovation and growth in this field.

\section{Method}

\subsection{Literature search and identification of studies}

Using the systematic review on the effects of business internships published by Sanahuja Velez \& Ribes Giner (2015), we identified a sample of studies related to the ITCs, published during the past ten years. We examined the selected articles in search of synergies and effects of the ITCs on business internships. We listed these effects using the 
approach of Perello \& Ribes (2014), which is an adaptation of the Q sorting (Petter, Straub \& Rai, 2007).

\subsection{Data collection and analysis of the existing conditions}

We obtained the numerical data about business internships through the official sources of the Universitat Politècnica de València. We consulted the Spanish legislation which regulates the business internships ("Real Decreto 592/2014 de 11 de julio, por el que se regulan las prácticas académicas externas de los estudiantes universitarios"), and the internal regulations of the Universitat Politècnica de València ("Reglamento sobre Prácticas en Empresas e Instituciones de los Estudiantes de la Universitat Politècnica de València”, approved by the Universitat Politècnica de València on the 28th of May of 2015) to picture and analyze the legal framework.

\section{Results}

\subsection{Business internships and their relation with new technologies}

The literature review yielded a total of five papers relevant to business internships and ICTs. Two studies were of a quantitative nature and three were qualitative. The findings related to new technologies found were listed and can be found in table 1 .

Table 1. Business internships and their relation to new technologies

(Qualitative studies in regular characters - Quantitative studies in italic characters)

\begin{tabular}{|c|c|c|}
\hline & Findings & Authors \\
\hline 1. & $\begin{array}{l}\text { Virtual internships increase computer and } \\
\text { ITCs skills. }\end{array}$ & $\begin{array}{l}\text { Franks \& Oliver (2012); Mihail } \\
\text { (2006) }\end{array}$ \\
\hline 2. & $\begin{array}{l}\text { Virtual internships develop independent } \\
\text { and critical thinking. Other skills learned } \\
\text { or enhanced include: project management, } \\
\text { independent work, research skills, virtual } \\
\text { presentations, teamwork. }\end{array}$ & Franks \& Oliver (2012) \\
\hline 3. & $\begin{array}{l}\text { Virtual internships provide new knowledge } \\
\text { and skills through social negotiation with } \\
\text { both the faculty internship supervisor and } \\
\text { the company supervisor (social learning } \\
\text { theory). }\end{array}$ & Franks \& Oliver (2012) \\
\hline
\end{tabular}


4. Blogging can enhance knowledge construction, reflection, learning, and communication of emotions.

5. Additional learning from social networking: managing a social media site, writing in a digital environment, learn to transfer social media personal skills to professional settings.

6. Virtual internships enable distance students to obtain industry appropriate experience.
Chu \& Chan (2010); Chu,

Kwan, \& Warning (2012)

McEachern (2011)

Conroy \& Khan (2008); Franks

\& Oliver (2012)

With the speedy expansion in the number of on-line enrollments in universities, educators have the challenge of warranting that work placement experiences are offered to distant students. Institutions of higher education are beginning to recognize the value of virtual internships as valid experiential learning as well as a good chance to acquire professional skills and competences (Franks \& Oliver, 2012). Some institutions are therefore integrating in their programs on-line virtual internships and thus allowing distant students to attain industry-relevant experience (Conroy \& Khan, 2008; Franks \& Oliver, 2012).

On the one hand, according to previous research, virtual internships offer the same benefits as place-based work placement, but they offer additional benefits as well, such as learning to use modern information and communication technology to perform their work and to cooperate with their site supervisor and co-workers (Franks \& Oliver, 2012). Virtual internships increase computer and ITCs skills (Mihail, 2006; Franks \& Oliver, 2012) and some other skills are also enhanced through virtual internships, such as working independently and critical thinking (Franks \& Oliver, 2010).

On the other hand, blogging has been recommended as a suitable tool for learning during traineeship due to its associated usefulness in collaborative learning, reflection, communication, and social support (Chu, Chan, \& Tiwari, 2010). The term "blog" is a shortened form of "web log", which is a web-based diary presented in reverse sequential order that consists of a person's opinions and thoughts published on the web for multiple viewers in a flexible way (Flatley, 2005). Some papers offered evidence to support the use of blogging during internship and computer-based tools for learning and teaching, and that blogs may be an appropriate learning platform that interns should engage in throughout their professional learning (Chu, et al., 2010; Chu, Kwan, \& Warning, 2012).

Finally, as social networking becomes progressively more popular as a communication tool for business and organizations, it is also vital that students learn to transfer personal social networking skills to professional situations. A study (McEachern, 2011) proved that this can be achieved through a Facebook Internship, experiencing a social network in the organizational context. 


\subsection{Business Internships at the Faculty of Business Administration and Management of the Universitat Politècnica de València}

The Faculty of Business Administration and Management of the Universitat Politècnica de València in Spain has a consolidated program of business internships. This institution is aware of the positive impact of business internships and therefore dedicates many efforts and resources to the organization, expansion, and improvement of the business internships. The result is that an increasing number of students has been able to undertake a work placement during their studies in this faculty of business during the past years, as table 2 evidences.

Table 2.- Number of Internships at the Faculty of Business Administration and Management of the Universitat Politècnica de València (2008-2015)

\begin{tabular}{llrlr}
\hline Year & $\begin{array}{l}\text { No. Internships at the } \\
\text { Faculty of Business } \\
\text { Administration and } \\
\text { Management }\end{array}$ & No. Employers & $\begin{array}{l}\text { No. Internships at } \\
\text { the Universitat } \\
\text { Politècnica de } \\
\text { València }\end{array}$ \\
\hline 2008 & 398 & 139 & 7,345 \\
2009 & 419 & 132 & 6,179 \\
2010 & 448 & 156 & 6,010 \\
2011 & 420 & 181 & 5,755 \\
2012 & 559 & 201 & 5,816 \\
2013 & 556 & 223 & 6,570 \\
2014 & 625 & 280 & 6,911 \\
2015 & 634 & 284 & 7,856 \\
\hline
\end{tabular}

Source: own elaboration using the official data provided by the Universitat Politècnica de València

In addition to the traditional Bachelor and Master Degrees in the field of business administration and management, the faculty has launched two Double Degrees: Business Administration and Management + Computer Science Engineering, and Business Administration and Management + Telecommunications Engineering. These two double degrees will provide the labor market with graduates strong in business administration and management skills but also with a deep knowledge of the ICTs, and they are expected to be highly demanded.

Furthermore, this faculty offers a modality of learning in a number of courses which is known as "flipped teaching", in which one of the characteristics is that part of the theoretical hours are instructed through the support of high quality audiovisual materials, instead of presence-based classes. 
At this moment the Universidad Politècnica de València is analyzing the situation and is aiming at launching a project in which virtual internships will be possible. We expect to provide empirical data of the first experiences in short as it will be paramount to assess this first experiences from the point of view of the satisfaction of participants and of the learning outcomes.

\section{Conclusions}

New technologies can enhance the traditional internship programs, in particular computer skills improvement and making the internship experience available to more students and companies, including distance students.

First of all, ICTs could enable the realization of virtual internships or telecommuted internships, which could make possible the internship experience to students and companies with difficulties of compatibility of space and in which on-line work would more efficient and recommended. Therefore there is the possibility of increasing the number of business internships and to expand their beneficial effects to a larger number of students and companies.

Secondly, the use of new technologies applied to business internships improves computer skills of its participants, as some authors have stressed in their researches. Also, the use of computer tools and social networks can enhance the overall learning outcomes of the internship experience.

Higher education institutions and administrations would be astute to stimulate virtual internship programs as a way of multiplying the valuable effects internships have on students in various spheres, especially on employability. This employability heightening is achieved through the ITCs competences that can be acquired, which are highly demanded by the work market.

Moreover, the possibility of undertaking a virtual internship in an international scope, could even add further beneficial effects to the work placement, as international internships have a lot to offer, particularly in terms of foreign languages improvement and intercultural skills enhancement. Virtual internships in a foreign country could also enable working in a different country without having to travel and this could be especially significant in moments or fields with difficulties, when it is problematic to find placements for all students. Also, companies in the foreign markets could benefit from experience, by hiring qualified employees among the Spanish students at a reasonable price.

If higher education institutions are committed to the employability of its university graduates, they should make business internships accessible to the maximum possible number of students and manage effective and adequate internship programs. They should also pay attention to the problems that can make students opt out of the valuable internship 
experience and accept the challenge of supporting students finding placements that will contribute positively to their career progress. One way could be, in the opinion of the authors, by being active in promoting virtual traineeships for its students, as well as attracting international virtual traineeships. Given that the Spanish law and that the regulations of the Universitat Politècnica de València allow internships in a foreign company and also bearing in mind the existing situation and conditions of the considered institution, the authors think that there is a space for innovation and growth in this field.

\section{References}

Beard, F., \& Morton, L. (1999). Effects of internship predictors on successful field experience. Journalism \& Mass Communication Educator, 72(2), 113-115.

Callanan, G., \& Benzing, C. (2004). Assessing the Role of Internships in the CareerOriented Employment of Graduating College Students. Education + Training, 46(2), 82-89.

Chen, C. H. (2011). A study of the effects of internship experiences on the behavioral intentions of college students majoring in leisure management in Taiwan. Journal of Hospitality Leisure Sport \& Tourism Education, 10(2), 61-73.

Chu, S.K.W., Chan, C.K.K., \& Tiwari, A.F.Y. (2010). Using Blogs to Support Learning during Internship. Computers \& Education, 58(3), 989-1000.

Chu, S.K.W., Kwan, A.C.M., \& Warning, P. (2012). Blogging for information management, learning, and social support during internship. Educational Technology \& Society, 15(2), 168-178.

Coco, M. (2000). Internships: a try before you by arrangement. SAM Advanced Management Journal, 65(2), 41-47.

Conroy, R., \& Khan, R. (2008). Integrating virtual internships into online classrooms. Journal of Commercial Biotechnology, 15(2), 97.

Divine, R.L., Linrud, J.K., Miller, R.H., \& Wilson, J.H. (2007). Required internship programs in marketing: Benefits, challenges and determinants of fit. Marketing Education Review, 17(2), 45-52.

Flatley, M. (2005). Blogging for enhanced teaching and learning. Business Communication Quarterly, 68(1), 77-80.

Franks, P.C., \& Oliver, G.C. (2012). Experiential learning and international collaboration opportunities: virtual internships. Library Review, 61(4), 272-285.

Gault, J., Leach, E., \& Duey, M. (2010). Effects of Business Internships on Job Marketability: The Employers' Perspective. Education \& Training, 52(1), 76-88.

Gault, J., Redington, J., \& Schlager, T. (2000). Undergraduate business internships and career success: are they related? Journal of Marketing Education, 22(1), 45-53.

Green, B.P., Graybeal, P., \& Madison, R.L. (2011). An Exploratory Study of the Effect of Professional Internships on Students' Perception of the Importance of Employment Traits. Journal of Education for Business, 86(2), 100-110. 
Gryski, G.S., Johnson, G.W., \& O’Toole, L.J. (1987). Undergraduate internships: an empirical review. Public Administration Quarterly, 11(2), 150-170.

Knouse, S.B., \& Fontenot, G. (2008). Benefits of the Business College Internship: A Research Review. Journal of Employment Counseling, 45(2), 61-66.

Knouse, S.B., John, R.T., Tanner, J.R., \& Harris, E.W. (1999). The relation of college internships, college performance and subsequent job opportunity. Journal of Employment Counseling, 36(1), 35-43.

McEachern, R.W. (2011). Experiencing a Social Network in an Organizational Context: The Facebook Internship. Business and Professional Communication Quarterly, 74(4), 486-493.

Mihail, D.M. (2006). Internships at Greek Universities: An Exploratory Study. Journal of Workplace Learning, 18(1), 28-41.

Perello-Marin, M. R., \& Ribes Giner, G. (2014). Identifying a guiding list of high involvement practices in human resource management. Working Papers on Operations Management, 5(1), 31-47.

Petter, S., Straub, D., \& Rai, A (2007). Specifying Formative Constructs in Information Systems Research, MIS Quarterly, 31(4), 623-656.

Real Decreto 592/2014 de 11 de julio, por el que se regulan las prácticas académicas externas de los estudiantes universitarios. BOE Núm. 184, July 13, 2014, 60502- 60511.

Reglamento sobre Prácticas en Empresas e Instituciones de los Estudiantes de la Universitat Politècnica de València", approved by the Universitat Politècnica de València on May 28, 2015.

Sanahuja Vélez, G., \& Ribes Giner, G. (2015). Effects of business internships on students, employers, and higher education institutions: a systematic review. Journal of Employment Counseling, 52(3), 121-130.

Scholz, R.W, Steiner, R., \& Hansmann, R. (2004). Role of Internship in Higher Education in Environmental Sciences. Journal of Research in Science Teaching, 41(1), 24-46.

Taylor, M.S. (1988). Effects of college internships on individual participants. Journal of Applied Psychology, 73(3), 393-401.

Theil, G.R., \& Hartley, N.T. (1997). Cooperative education: A natural synergy between business and academia. SAM Advanced Management Journal, 62(3), 19-24.

Weible, R., \& McClure, R. (2011). An Exploration of the Benefits of Student Internships to Marketing Departments. Marketing Education Review, 21(3), 229-240. 